\title{
IMPACT OF LATVIAN WOOD CONSTRUCTION CLUSTER ON THE ECONOMIC EFFICIENCY OF ITS MEMBERS
}

\author{
Aina Muska ${ }^{1}$, Dr.oec., associate professor; Gunita Mazure², Dr.oec., associate professor and \\ Kristaps Muska ${ }^{3}$ \\ 1,2Latvia University of Life Sciences and Technologies \\ ${ }^{3}$ Jelgava Spidola State Gymnasium
}

\begin{abstract}
The operation in the cluster allows merchants increase their operational efficiency, productivity, exportability and gain other benefits. The establishment of Latvian Wood Construction Cluster at the beginning of 2012 was targeted at promotion of the cooperation within the industry by developing the potential of production and export markets. The research aim is to study the changes in the economic efficiency of the merchants belonging to Latvian Wood Construction Cluster. Six Cluster members, whose economic efficiency was measured consistent with the methodology developed by the research authors, were selected for the validation or rejection of the research hypothesis and achievement of the research aim, which was advanced following the recommendation of the experts. The research results lead to the conclusion that the economic efficiency of the merchants under the study has not improved during the Cluster performance period; it has even worsened, especially for "Nordic Homes", "HUSVIK", "Dores fabrika" and "Cross Timber Systems", compared with the average industry figure. Nevertheless, the net sales, operating profit and net profit of "BYKO-LAT" have increased during the Cluster performance period and the achieved results have significantly surpassed the average industry figures, the merchant's economic efficiency did not present an improvement during the Cluster performance period due to the decline in return on assets, increase in production costs, decline in the profit to long-term capital ratio in 2017 and 2018 as well as the decrease in return on equity and commercial profitability in 2018 . The authors explain the obtained research results by the fact that the Cluster activities are performed with the aim to inform on the Cluster operation, its members and wood construction; the Cluster activities are less targeted at the increase of economic efficiency.
\end{abstract}

Key words: cluster, economic activities, efficiency.

JEL code: M21

\section{Introduction}

In Latvia, the cluster initiative is a relatively new activity, though a successful economic development in many countries of the world is based on clusters; thus, achieving a prosperous cooperation among competing merchants in the same industry, scientific research institutions and government institutions. The operation in the cluster allows merchants to increase their operational efficiency, exportability and gain other benefits. Also several Latvian researchers (e.g. Garanti (2015), Kassalis (2014) etc.) indicate that the operation of merchants in the cluster contributes to the increase of its efficiency, productivity, competitiveness, growth, introduction of innovation, establishment of new companies and viability. Latvian Wood Construction Cluster was established at the beginning of 2012 with the aim to promote the cooperation of merchants within the industry by developing the potential of production and export markets. Consequently, the Cluster has been already operating for eight years and it is possible to make the first detailed measurements of the Cluster performance. The research hypothesis - membership of a merchant in Latvian Wood Construction Cluster raises the efficiency of its economic activity. The research aim - to study the changes in the economic efficiency of the merchants belonging to Latvian Wood Construction Cluster.

The research tasks: 1 ) to characterise the research objects; 2) to develop a methodology for the assessment of the changes in the economic efficiency; 3) to evaluate the impact on the economic efficiency of the merchants belonging to the Cluster with help of the developed methodology.

As Latvian Wood Construction Cluster has been operating since 2012, the research covers the period from 2013 to 2018. I. Ffowcs-Williams (2010), a cluster researcher, believes that it is 
expedient to initiate the first measurements of the cluster performance three years after the beginning of the cluster operation; thus, the research period was divided into two stages: preperformance period (2013-2015) and cluster performance period (2016-2018). The present research is bzased on the data of the Central Statistical Bureau and Lursoft database, publications of the Ministry of Economics and findings of Latvian and foreign researchers. The research employs general scientific research methods (monographic, graphic and logically-constructive methods as well as the method of analysis and synthesis), sociological research methods (analysis of documents, expert survey) and economically statistical method (time series). The research novelty - a performance study of the impact of Latvian Wood Construction Cluster was done consistent with the methodology developed by the authors of the present research.

\section{Research results and discussion}

\section{Characteristics of the research object}

Latvian Wood Construction Cluster was established by uniting more than 20 manufacturers of wooden houses and education and research institutions to promote the cooperation within the industry by developing the potential of production and export markets. The essence and aim of the Cluster prescribe that the economic activities of its members should improve as a result of their membership. At the beginning of 2020, the Cluster united 23 manufacturers, 3 education institutions and 2 research institutions. Six out of twenty-three Cluster members were selected for the present research based on the recommendation of the expert (managing director of Latvian Wood Construction Cluster): SIA "Dores fabrika" (produces square log houses), SIA "Cross Timber Systems" (produces CLT houses), SIA "HUSVIK" (produces frame houses), SIA "Nordic Homes" (produces modular houses), SIA "Zemgales tehnologiskais centrs" (produces frame houses) and SIA "BYKO-LAT" (produces frame houses and modular houses) (Latvian Wood Construction Cluster, [s.a.]).

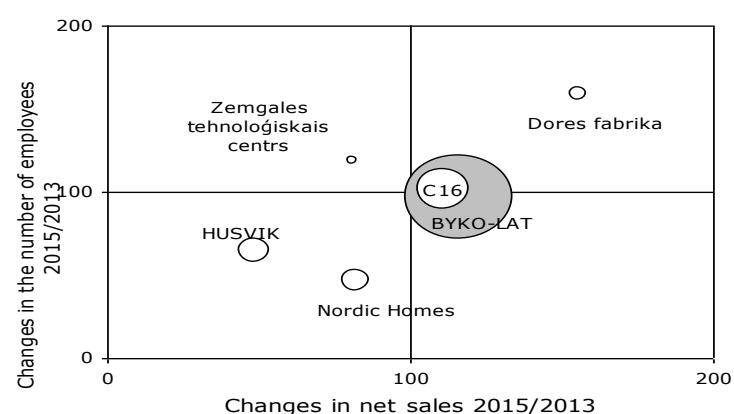

A

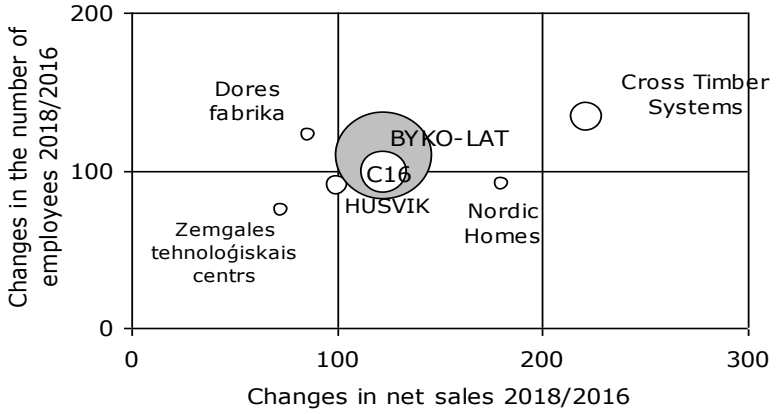

B

Note: size of the circle reflects the share of a merchant's net sales in total net sales of merchants under the study Source: authors' calculations based on the data of the Central Statistical Bureau (s.a.) and Lursoft Ltd (s.a.)

Fig. 1. The changes in net sales and the number of employees of the merchants under the study during the Cluster pre-performance period (A) and the Cluster performance period (B), \%

Based on the study results of three cluster performance evaluation methods: Varmland method Scottish method, Cluster Navigats method (Kassalis, 2014), two indicators - net sales and the number of employees - which are recommended as the indicators to be evaluated by all the three methods, were chosen for the characterisation of merchants under the study. In addition, these were the indicators the research authors had data available on. For the purpose of analysis, the two indicators were compared with the data of Sector C16 - Manufacture of wood and of products of 
wood and cork, except furniture; manufacture of articles of straw and plaiting materials (hereinafter - Sector C16).

Data of Figure 1.A. show that within the period 2013-2015 or the Cluster pre-performance period the net sales growth $(+11 \%)$ in Sector C16 was faster than the changes in the number of employees $(+1 \%)$, which means that the net sales changes in the Sector were based on the productivity growth rather than on the increase in the number of employees.

During the Cluster pre-performance period, total net sales of Sector C16 increased, while its growth rate was gradually decreasing, which may be explained by the changes in output volume and prices. In 2013 and 2014, the growth of Sector C16 was driven by the increase in output volume and prices, which also led to an increase in net sales (Ekonomikas ministrija, 2013, 2014). In 2015, the global price fall left an impact on the decrease of sales growth rate. Another factor was the increase in the volume of exported production in 2015 with the corresponding decrease in the domestic market (Ekonomikas ministrija, 2015). The construction sector is one of the main consumers of Sector C16 production in the domestic market. The Central Statistical Bureau data (s.a.) show that the changes in construction output were negative, i.e. - $1.2 \%$ in 2015 compared with the previous year.

Changes in the number of employees of Sector C16 are similar to those in net sales: the chain increase rate gradually declines and it was negative in 2015. According to an industry expert (executive director of Latvian Forest Industry Federation), the decline in the number of employees is related with the modernisation of production process leading to the replacement of labour force with equipment.

Among the merchants under the study only "BYKO-LAT" had based the changes in net sales on the increase of productivity, where the net sales grew by $16 \%$, i.e. faster than in the entire Sector C16, while the number of employees dropped by $3 \%$. The increase in net sales of "Dores fabrika" (by $55 \%$ ) relates with the growth in the number of employees (by $59 \%$ ). Other merchants under the study have experienced a decrease in net sales; especially a rapid decline was experienced by "HUSVIK" (by $52 \%$ ). The increase in the number of employees of "Zemgales tehnologiskais centrs" (by $19 \%$ ) did not ensure an increase of net sales, it even decreased by $19 \%$. Analysing changes in the balance sheets of the merchants under the study the authors came to the conclusion that only "BYKO-LAT" had invested in fixed assets, which allowed to reduce the number of employees. Other merchants under the study have not invested in modernisation; yet, they have experienced an increase in the number of employees. Figure 1.A does not include "Cross Timber Systems", since the production and sales of CLT houses was launched only in 2015.

During the Cluster performance period (2016-2018) the net sales of Sector C16 have increased by $23 \%$, while the number of employees has decreased by $2 \%$. This means that the changes in net sales of the Sector were basically driven by the productivity growth. Total net sales of Sector C16 in the Cluster performance period gradually rose with a more intense chain increase rate. In contrast, the number of employees in the Sector gradually declined in 2016 and 2017. In 2016, the declines related with the modernisation of production processes, while in 2017 , the decrease in the number of employees was affected by bad weather conditions leading to a shortage of raw materials in the entire country by the end of 2017, which forced almost all log processing plants to reduce the length or number of shifts (Kirsons, 2018). In 2018, the number of employees in Sector C16 has slightly increased (by $0.3 \%$ ). The sales growth in Sector C16 was driven by the global price increase across Europe (Ekonomikas ministrija, 2018, 2019). 
During the Cluster performance period the changes in net sales among the merchants under the study were based on the productivity growth for four merchants: "Cross Timber Systems" (net sales grew by $122 \%$, while the number of employees increased by $33 \%$ ), "BYKO-LAT" (by $23 \%$ and $9 \%$, respectively), "Nordic Homes" (the respective changes were $+80 \%$ and $-9 \%$ ) and "HUSVIK" (the respective changes were $+1 \%$ and $-10 \%$ ). Net sales of two other merchants ("Dores fabrika" and "Zemgales tehnologiskais centrs") decreased more rapid than the number of employees.

It may be observed from the data of Figure 1 that "BYKO-LAT" is the largest by net sales among the analysed merchants both in the Cluster pre-performance period and performance period: the share of its net sales constitutes $80 \%$ of total net sales of the merchants under the study. "BYKO-LAT" is also among the ten largest forest industry merchants in Latvia in terms of net sales. "BYKO-LAT" is also the largest employer among the merchants under the study.

\section{Research methodology for assessing the efficiency of economic activity}

Seven indicators are used to characterise the efficiency of economic activity: net profit, operating profit, commercial profitability, return on assets, return on equity, net profit to equity ratio and net profit to non-current liabilities or long-term capital as well as total production costs to net sales ratio (Rurane, 2001). The calculated indicators were compared with the indicators of previous periods and the average level of the sector (Sector C16). The statistical database of the Central Statistical Bureau provides all the data of Sector $\mathrm{C} 16$ selected for the analysis except two indicators: operating profit and total production costs to net sales ratio. These indicators were compared with the arithmetic mean of the merchants under the study.

The calculated figures were expressed in a scale from minus 3 to plus 3 to unite all seven indicators characterising the efficiency of economic activity into a single system and to determine the changes among the merchants under the study during the analysed periods. Zero points mean that the indicator achieved by a merchant under the study equals to the industry level in the respective survey year. One point means that the difference between the indicator achieved by a merchant under the study and the industry level by module does not exceed the value of the industry indicator in the respective year. Two points mean that the difference between the indicator achieved by a merchant under the study and the industry level by module exceeds the value of the industry indicator in the respective year; though the excess is less than two times. Three points mean that the difference between the indicator achieved by a merchant under the study and the industry level by module exceeds the value of the industry indicator in the respective year two or more times. If the difference is negative, the score awarded is preceded by a minus sign, if the difference is positive, then - a plus sign.

The scores obtained were summed up separately for the pre-performance period and the Cluster performance period and total scores for both periods were compared thereafter. If the total score of indicators for the Cluster performance period increased compared with the pre-performance period, the authors assume that the membership of a merchant in the Cluster has improved its economic efficiency, if the score decreases, then - the membership of a merchant in the Cluster has not left an impact on its economic efficiency.

\section{Characterisation and evaluation of the economic activity efficiency of merchants belonging to the Cluster}

The authors begin their analysis with the net profit. Throughout the study, Sector C16 has been operating with net profit both as a whole and per one merchant of the Sector on average. Net profit 
has gradually increased within the analysed period, except for 2015, when it decreased both as a whole and on average in the Sector compared with 2014. According to the forest industry experts, the decline related with the stagnation or even decline of prices in the global market; though, operating costs have grown that year in Latvia leading to a decrease in net profit (Kirsons, 2017). Net profit of Sector C16 has steadily risen during the Cluster performance period, especially within the previous two years (by $67 \%$ in 2017 and $41 \%$ in 2018).

Analysing the merchants under the study, the authors conclude that only two ("BYKO-LAT" and "Zemgales tehnologiskais centrs") of six merchants have generated net profit both in the preperformance and the Cluster performance period. Net profit of "BYKO-LAT" has increased in the preperformance period, while it has decreased in 2016 and then again increased in the following two years. Data of Table 1 allow concluding that the net profit of "BYKO-LAT" has several times exceeded the average net profit of Sector C16 throughout the study period. Nevertheless "Zemgales tehnologiskais centrs" has operated with a profit during the study period, the amount of profit has been below the average net profit level of Sector C16, except for 2016, when its net profit exceeded the average level by $23 \%$.

The other merchants under the study have been operating with loss with the exception of "HUSVIK" (in 2013), "Nordic Homes" (in 2014) and "Cross Timber Systems" (in 2018), when these merchants closed their business years with profit. In general, it should be concluded that the variations in losses of the merchants under the study are wave-like with an increasing trend both in the pre-performance and the Cluster performance period.

The research authors have also analysed the net profit to loss balance ratio (sum of total net profit and total net losses of the merchants under the study), which proved to be negative both in 2013 (EUR 503 thou.) and 2016 (EUR 56 thou.). This means that total losses of the merchants under the study have exceeded total profit; though, the share of losses has essentially declined during Year 1 of the Cluster performance period. The balance is positive in the other years; however, the excess of total net profit over losses is higher in the Cluster pre-performance period compared with the Cluster performance period. The feature may be explained by a significant impact of the "BYKO-LAT" ratio (the share of "BYKO-LAT" net profit in total profit of the merchants under the study is over $90 \%$ ) on total profit figures of the merchants under the study. Since the net profit of "BYKO-LAT" was smaller in the Cluster performance period compared with the pre-performance period, it has also left an impact on the total value of the ratio net profit to loss balance.

The comparison of the net profit to loss and operating profit to loss ratios for the merchants under the study showed similar tendencies. Analysing the operating profit to loss balance ratio, the authors concluded that it was negative only in 2013 (almost EUR 600 thou.), while it was positive in the rest of the years despite the fact that basically two merchants ("BYKO-LAT" un "Zemgales tehnologiskais centrs") closed their economic activities with operating profit. The analysis of total operating losses among the merchants under the study operating with loss allows concluding that losses have increased in 2015 and 2016 with the increase of business costs in Latvia and stagnation or even decrease of prices in the global market. Total operating profit dropped also for those merchants under the study who operated with profit in 2016 due to the same reason. In 2017 and 2018, operating losses shrank both totally and individually for merchants operating with loss, excluding "Nordic Homes", whose operating losses grew significantly. The operating profit of "BYKO-LAT" increased, while it gradually lessened for "Zemgales tehnologiskais centrs" during the Cluster performance period. 
Commercial profitability is a relative metrics characterising return on sales and assessing the income (profit or loss) to net sales unit.

During the Cluster pre-performance period, the trend of commercial profitability in Sector C16 is wavy-like: in 2013 and 2015, the commercial profitability lowered due to the decrease of net profit in the Sector, while net sales continued to increase, though at a slower pace. In 2014 and the Cluster performance period, a faster chain increase rate of net profit compared with the increase rate of net sales in Sector $\mathrm{C} 16$ ensured the increase of commercial profitability. During the Cluster performance period commercial profitability in Sector C16 (5.2 \%, 8.3 \% and $10.0 \%$, respectively) surpasses the level of 2014.

Since only two merchants during the entire study period closed their economic activities with net profit, exactly these merchants have positive commercial profitability, while the data of Table 1 evidence that the level of their commercial profitability has been lower than the average ratio of Sector C16. The exception is 2015, when the commercial profitability of "BYKO-LAT" was more than twice the average ratio of Sector $\mathrm{C} 16$. The general conclusion is that the membership has not helped improve commercial profitability of merchants belonging to the Cluster with the exception of "Cross Timber Systems" whose commercial profitability has risen from $-23.8 \%$ to $+2.5 \%$ during the Cluster performance period; though, the figures are worse than the average sector ratios. "HUSVIK" is the other merchant whose negative commercial profitability has declined from $-6.5 \%$ in 2016 to $-2 \%$ in 2018.

The next two relative indicators analysed are return on equity, which is the ratio of net profit to the annual average value of equity and the ratio of net profit to the annual average value of equity and the annual average value of long-term liabilities. The obtained data showed that the two analysed profitability trends throughout the study period are similar with the commercial profitability figures both for the Sector C16 as a whole and the analysed merchants with the exception of "BYKO-LAT", which had achieved a slightly higher level of return on equity not only in 2015 but also in 2014 and 2016 as well as in 2016 - the level of equity to long-term capital was higher than the average level of Sector C16.

The same trend was also identified for the return on assets, which characterises the ratio of operating profit to the annual average value of assets.

The last analysed indicator was the ratio of total production costs to net sales or the share of production costs in net sales. The share of production costs in net sales has not exceeded $100 \%$ throughout the study period, which means that operating revenues ensured the recovery of production costs for three merchants under the study: "Zemgales tehnologiskais centrs", "BYKO-LAT" and "Dores fabrika". The calculated figures for these merchants had a declining trend during the preperformance period, while it had an increasing trend during the Cluster performance period. In 2015, the production costs of "Cross Timber Systems" surpassed net sales, while the share of production costs in net sales was below $100 \%$ during the Cluster performance period with a gradual declining trend. In 2017 and 2018, "HUSVIK" that could not cover production costs by net sales in 2015 and 2016 managed to significantly reduce the share of production costs below $90 \%$. The worst figures in the Cluster performance period among the merchants under the study were presented by "Nordic Homes", which was able to cover production costs by net sales only in 2017. In general, "Zemgales tehnologiskais centrs" has presented the lowest share of production costs in net sales throughout the analysed period. 
The calculated indicators describing the economic efficiency were expressed in a scale of -3 to +3 consistent with the developed methodology (Table 1).

Table 1

Total assessment of economic efficiency indicators, points

\begin{tabular}{|c|c|c|c|c|c|c|c|c|c|}
\hline \multirow{3}{*}{ Merchants under the study } & \multicolumn{4}{|c|}{ Pre-performance period } & \multicolumn{4}{|c|}{ Cluster performance period } & \multirow{2}{*}{ 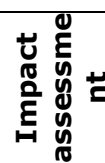 } \\
\hline & 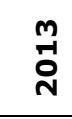 & $\underset{\text { d }}{\stackrel{+}{0}}$ & ำ & $\begin{array}{l}\bar{J} \\
\stackrel{0}{\circ}\end{array}$ & $\begin{array}{l}0 \\
-1 \\
0\end{array}$ & 今े & 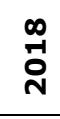 & $\begin{array}{l}\overline{8} \\
\stackrel{0}{\circ}\end{array}$ & \\
\hline & \multicolumn{8}{|c|}{ Net profit/loss } & \\
\hline Dores fabrika & -2 & -3 & -3 & -8 & -3 & -3 & -3 & -9 & $\downarrow$ \\
\hline Cross Timber Systems & -2 & -3 & -3 & -8 & -3 & -3 & +1 & -5 & $\uparrow$ \\
\hline HUSVIK & +3 & -3 & -3 & -3 & -3 & -3 & -2 & -8 & $\downarrow$ \\
\hline Nordic Homes & -3 & +3 & -3 & -3 & -3 & -3 & -3 & -9 & $\downarrow$ \\
\hline Zemgales tehnologiskais centrs & -1 & -1 & -1 & -3 & +1 & -1 & -1 & -1 & $\uparrow$ \\
\hline \multirow[t]{2}{*}{ BYKO-LAT } & +3 & +3 & +3 & +9 & +3 & +3 & +3 & +9 & $\rightarrow$ \\
\hline & \multicolumn{8}{|c|}{ Operating profit/loss } & \\
\hline Dores fabrika & +2 & -2 & -2 & -2 & -2 & -2 & -2 & -6 & $\downarrow$ \\
\hline Cross Timber Systems & +1 & -2 & -3 & -4 & -3 & -3 & -1 & -7 & $\downarrow$ \\
\hline HUSVIK & +3 & -3 & -2 & -2 & -2 & -3 & -2 & -7 & $\downarrow$ \\
\hline Nordic Homes & -3 & +1 & -3 & -5 & -3 & -3 & -3 & -9 & $\downarrow$ \\
\hline Zemgales tehnologiskais centrs & +2 & -1 & -1 & 0 & -1 & -1 & -1 & -3 & $\downarrow$ \\
\hline \multirow[t]{2}{*}{ BYKO-LAT } & +3 & +3 & +3 & +9 & +3 & +3 & +3 & +9 & $\rightarrow$ \\
\hline & \multicolumn{8}{|c|}{ Commercial profitability } & \\
\hline Dores fabrika & -2 & -2 & -3 & -7 & -3 & -3 & -3 & -9 & $\downarrow$ \\
\hline Cross Timber Systems & 0 & 0 & -3 & -3 & -3 & -3 & -1 & -7 & $\downarrow$ \\
\hline HUSVIK & +1 & -3 & -3 & -5 & -3 & -3 & -2 & -8 & $\downarrow$ \\
\hline Nordic Homes & -3 & -1 & -3 & -7 & -3 & -3 & -3 & -9 & $\downarrow$ \\
\hline Zemgales tehnologiskais centrs & -1 & -1 & -1 & -3 & -1 & -1 & -1 & -3 & $\rightarrow$ \\
\hline \multirow[t]{2}{*}{ BYKO-LAT } & -1 & -1 & +2 & 0 & -1 & -1 & -1 & -3 & $\downarrow$ \\
\hline & \multicolumn{8}{|c|}{ Return on equity } & \\
\hline Dores fabrika & -2 & -2 & -3 & -7 & -2 & -3 & -3 & -8 & $\downarrow$ \\
\hline Cross Timber Systems & +3 & -3 & -3 & -3 & -3 & -3 & +1 & -5 & $\downarrow$ \\
\hline HUSVIK & +3 & -3 & -3 & -3 & -3 & +3 & +3 & +3 & $\uparrow$ \\
\hline Nordic Homes & +3 & -3 & -3 & -3 & +3 & +3 & -3 & +3 & $\uparrow$ \\
\hline Zemgales tehnologiskais centrs & -1 & -1 & -1 & -3 & -1 & -1 & -1 & -3 & $\rightarrow$ \\
\hline \multirow[t]{2}{*}{ BYKO-LAT } & -1 & +1 & +2 & +2 & +1 & -1 & -1 & -1 & $\downarrow$ \\
\hline & \multicolumn{8}{|c|}{ Profit to long-term capital } & \\
\hline Dores fabrika & -3 & -2 & -2 & -7 & -3 & -2 & -3 & -8 & $\downarrow$ \\
\hline Cross Timber Systems & +1 & -2 & -2 & -3 & -3 & -3 & -3 & -9 & $\downarrow$ \\
\hline HUSVIK & -1 & +2 & -3 & -2 & -3 & -3 & -3 & -9 & $\downarrow$ \\
\hline Nordic Homes & +3 & -3 & +1 & +1 & -3 & -3 & -3 & -9 & $\downarrow$ \\
\hline Zemgales tehnologiskais centrs & -1 & -1 & -1 & -3 & -1 & -1 & -1 & -3 & $\rightarrow$ \\
\hline \multirow[t]{2}{*}{ BYKO-LAT } & -1 & -1 & +1 & -1 & 3 & -1 & -1 & +1 & $\uparrow$ \\
\hline & \multicolumn{8}{|c|}{ Return on assets } & \\
\hline Dores fabrika & -1 & -2 & -3 & -6 & -2 & -3 & -2 & -7 & $\downarrow$ \\
\hline Cross Timber Systems & -3 & -2 & -3 & -8 & -2 & -2 & -1 & -5 & $\uparrow$ \\
\hline HUSVIK & +2 & -3 & -3 & -4 & -2 & -3 & -2 & -7 & $\downarrow$ \\
\hline Nordic Homes & -3 & +2 & -3 & -4 & -3 & -3 & -3 & -9 & $\downarrow$ \\
\hline Zemgales tehnologiskais centrs & -1 & -1 & -1 & -3 & +1 & -1 & -1 & -1 & $\uparrow$ \\
\hline BYKO-LAT & -1 & +1 & +3 & +3 & +2 & +1 & -1 & +2 & $\downarrow$ \\
\hline
\end{tabular}




\begin{tabular}{|c|c|c|c|c|c|c|c|c|c|}
\hline \multirow[b]{2}{*}{ Merchants under the study } & \multicolumn{4}{|c|}{ Pre-performance period } & \multicolumn{4}{|c|}{ Cluster performance period } & \multirow{2}{*}{ 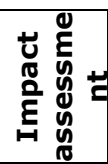 } \\
\hline & 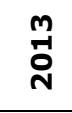 & ষ্ণ & 물 & $\begin{array}{l}\bar{\pi} \\
\stackrel{0}{0}\end{array}$ & 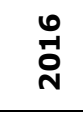 & 今. & $\begin{array}{l}\infty \\
\underset{\mathbf{N}}{\mathbf{N}}\end{array}$ & $\begin{array}{l}\bar{\pi} \\
\stackrel{0}{\circ}\end{array}$ & \\
\hline & \multicolumn{8}{|c|}{ Share of production costs in net sales } & \\
\hline Dores fabrika & +1 & +1 & +1 & +3 & +1 & -1 & -1 & -1 & $\downarrow$ \\
\hline Cross Timber Systems & 0 & 0 & -1 & -1 & +1 & -1 & -1 & -1 & $\rightarrow$ \\
\hline HUSVIK & +1 & -1 & -1 & -1 & -1 & 0 & +1 & $\mathbf{0}$ & $\uparrow$ \\
\hline Nordic Homes & -1 & +1 & +1 & +1 & -1 & -1 & -1 & -3 & $\downarrow$ \\
\hline Zemgales tehnologiskais centrs & +1 & +1 & +1 & +3 & +1 & +1 & +1 & +3 & $\rightarrow$ \\
\hline BYKO-LAT & -1 & -1 & +1 & -1 & +1 & 0 & 0 & +1 & $\uparrow$ \\
\hline
\end{tabular}

Source: authors' calculations based on the developed methodology

The research results indicate that the economic efficiency of merchants has not improved during the Cluster performance period, it has even worsened compared with the average indicators of Sector C16, especially that of "Nordic Homes" (decrease of economic efficiency by 25 points: from -20 points in the pre-performance period to -45 points in the Cluster performance period), "HUSVIK" (decrease by 16 points: from -20 to -36 points) and "Dores fabrika" (by 14 points: from -34 to -48 points). The economic efficiency of "Cross Timber Systems" has also worsened (from -30 points to -39 points). Nevertheless net sales, operating profit and net profit of "BYKO-LAT" have increased during the Cluster performance period and the achieved indicators have been significantly above the average figures of the Sector, the operating efficiency of the merchant has not improved throughout the Cluster performance period due to the decline of return on assets, increase of production costs, decrease of the profit to long-term capital ratio in 2017 and 2018 as well as the decrease of return on equity and commercial profitability in 2018.

No significant changes were observed in the economic efficiency of "Zemgales tehnologiskais centrs"; though, the analysed indicators have essentially worsened in 2018. Throughout the whole analysed period the indicators achieved by the merchant have been below the average level of Sector C16.

The authors explain the obtained results by the fact that the activities implemented by the Cluster are aimed at information on the Cluster operation, its members and wood construction. The Cluster activities are less aimed at the increase of operating efficiency and competitiveness. During the period 2017-2020, the Cluster is implementing the project "Promotion of International Competitiveness of Wood Construction Cluster" (total budget - EUR 488 220) co-financed by the European Regional Development Fund with the aim to enhance the development of merchants belonging to the wood construction sector in domestic and foreign markets. The main activities of the project relate with the implementation of information campaigns, organisation of workshops, research publications and transformation of the Cluster website into a sales platform. Among the four planned results, one is related with the increase of export volumes of the Cluster members by at least $10 \%$ and sales - by at least $6 \%$, which the research authors believe to be modest (Latvian Wood Construction Cluster, [s.a.]).

\section{Conclusions, proposals, recommendations}

1) The overall economic efficiency of the merchants under the study has not improved during the Cluster performance period (2016-2018) compared with the Cluster pre-performance period (2013-2015). It has even worsened; thus, rejecting the research hypothesis. 
2) The economic efficiency has significantly decreased for "Nordic Homes" (by 25 points or 2.25 times), "HUSVIK" (by 16 points or 1.8 times), "Dores fabrika" (by 14 points or 1.4 times) and "Cross Timber Systems" (by 9 points or 1.3 times).

3) Nevertheless net sales, operating profit and net profit of "BYKO-LAT" have increased during the Cluster performance period and the achieved indicators have been significantly above the average figures of the Sector, the economic efficiency of the merchant has not improved throughout the Cluster performance period due to the decline of return on assets, increase of production costs, decrease of the profit to long-term capital ratio in 2017 and 2018 as well as the decrease of return on equity and commercial profitability in 2018 .

4) The economic efficiency of "Zemgales tehnologiskais centrs" has not changed significantly, while the analysed indicators have essentially worsened in 2018. Throughout the whole analysed period the indicators achieved by the merchant have been below the average level of Sector C16.

5) The methodology for the evaluation of the Cluster performance developed by the research authors shall be approbated also on the basis of merchants belonging to other clusters.

\section{Bibliography}

1. Central Statistical Bureau of Latvia (CSB) ([s.a.]). Statistics Database. Retrieved: https://www.csb.gov.Iv/en/statistics. Access: 02.01.2020. (Tables SBG010, UFG030, UFG040, UFG050, UFG070, BUG020)

2. Ekonomikas ministrija (Ministry of Economics) (2013). Zinojums par Latvijas tautsaimniecības attistibu (Report on Economic Development of Latvia). Riga, 37.lpp.

3. Ekonomikas ministrija (Ministry of Economics) (2014). Zinojums par Latvijas tautsaimniecības attistibu (Report on Economic Development of Latvia).Riga, 39.Ipp.

4. Ekonomikas ministrija (Ministry of Economics) (2015). Zinojums par Latvijas tautsaimniecības attistibu (Report on Economic Development of Latvia).Riga, 39.Ipp.

5. Ekonomikas ministrija (Ministry of Economics) (2016). Zinojums par Latvijas tautsaimniecības attistibu (Report on Economic Development of Latvia).Riga, 43.Ipp.

6. Ekonomikas ministrija (Ministry of Economics) (2018). Latvijas ekonomikas attistibas parskats (Review on the Economic Development of Latvia). Riga, 37.Ipp.

7. Ekonomikas ministrija (Ministry of Economics) (2019). Latvijas ekonomikas attistibas parskats (Review on the Economic Development of Latvia).Riga, 37.Ipp.

8. Ffowcs-Williams, I. (2010). Cluster Development Course: Workshop material. Cluster Navigators, Investment and Development Agency of Latvia. Riga, Latvia.

9. Garanti, Z. (2015). Regional Cluster Establishment and Development Possibilities in Latvia (Regionalo klasteru izveides un attistibas iespejas Latvija): Promocijas darbs ekonomikas doktora (Dr.oec.) zinatniska grada iegusanai. Jelgava: LLU, $174 \mathrm{lpp}$.

10. Kassalis, I. (2014). Ostu klasteru izvertejums un sniegums Latvijas ekonomiskaja izaugsme (Evaluation and Performance of Port Clusters for the Economic Growth of Latvia): Promocijas darbs doktora zinatniska grada iegusanai ekonomikas nozare. Riga: Latvijas Universitate, 189 Ipp.

11. Kirsons, M. (2017). Globalo notikumu ietekme (Impact of Global Events). Top 500 Latvijas lielakie uznemumi: Laikraksta Dienas Bizness pielikums. Riga: Diena-Bonnier, 94.-95.Ipp.

12. Kirsons, M. (2018). Pielagojoties trim gadalaikiem (Adapting to Three Seasons). Top 500 Latvijas lielakie uznemumi: Laikraksta Dienas Bizness pielikums. Riga: Diena-Bonnier, 90.Ipp.

13. Latvia Wood Construction Cluster: [Latvijas koka buvniecības klastera majaslapa] ([s.a.]). Retrieved: https://woodhouses.Iv/en Access: 02.01.2020.

14. Lursoft Ltd. ([s.a.]). Database of All Companies Registered in Latvia. Retrieved: https://www.lursoft.Iv/en/data-bases-of-enterprises. Access: 02.01.2020. (Dores fabrika Ltd, Cross Timber Systems Ltd, HUSVIK Ltd, Nordic Homes Ltd, Zemgales tehnologiskais centrs Ltd, BYKO-LAT Ltd)

15. Rurane, M. (2001). Finansu parvaldiba (Financial Management). Riga: Latvijas izglitibas fonds, pp.189-245. 